${ }^{4}$ Hosking DJ. Treatment of severe hypercalcaemia with calcitonin. Metabolic Bone Disease and Related Research 1980;2:207-12.

${ }^{5}$ Sherwood JK, Ackroyd FW, Garcia M. Effect of cimetidine on circulating parathyroid hormone in primary hyperparathyroidism. Lancet $1980 ; \mathrm{i}$ : 616-9.

${ }^{6}$ Palmer FJ, Sawyers TM, Wierzbinski SJ. Cimetidine and hyperparathyroidism. N Engl f Med 1980;302:692.

7 Heath H. Cimetidine in hyperparathyroidism. Lancet 1980;i:980.

${ }^{8}$ Frijlink WB, Bijvoet OLM, Velde J, Heynen G. Treatment of Paget's disease with (3-amino-1-hydroxypropylidene)-1,1-bisphosphonate (APD). Lancet 1979;i:799-803.

${ }^{9}$ Meunier PJ, Chapuy MC, Alexandre C, et al. Effects of disodium dichloromethylene diphosphonate on Paget's disease of bone. Lancet 1979 ;ii : $489-92$.

${ }^{10}$ Douglas DL, Duckworth T, Russell RGGR, et al. Effect of dichloromethylene diphosphonate in Paget's disease of bone and in hypercalcaemia due to primary hyperparathyroidism or malignant disease. Lancet 1980; i:1043-7.

11 Douglas DL, Duckworth T, Kanis JA, et al. Biochemical and clinical responses to dichloromethylene diphosphonate $\left(\mathrm{Cl}_{2} \mathrm{MDP}\right)$ in Paget's disease of bone. Arthritis Rheum 1980;23:1185-92.

12 van Breukelen FJM, Bijvoet OLM, van Oosterom AT. Inhibition of osteolytic bone lesions by 3-amino-1-hydroxypropylidene-1,1 bisphosphonate (APD). Lancet 1979; i:803-5.

${ }^{13}$ Siris ES, Sherman WH, Baquiran DC, Schlatterer JP, Osserman EF, Canfield RE. Effects of dichloromethylene diphosphonate on skeletal mobilisation of calcium in multiple myeloma. $N$ Engl f Med 1980; 302:310-5.
${ }^{14}$ Chapuy MC, Meunier PJ, Alexandre CM. Effects of disodium dichloromethylene diphosponate on hypercalcaemia produced by bone metastases. 7 Clin Invest 1980;65:1243-7.

15 Shane E, Baquiran DC, Bilezikian JP. Effects of dichloromethylene diphosphonate on serum and urinary calcium in primary hyperparathyroidism. Ann Intern Med $1981 ; 95: 23-7$.

${ }^{16}$ Stegemann H. Mikrobestimmung von Hydroxyprolin mit Chloramin-T und p-Dimethylamino-benzaldehyd. Hoppe-Seyler's Zeitschrift für physiologishe Chemie 1958;311:41-5.

${ }^{17}$ Bijvoet OLM, Morgan DB, Fourman P. The assessment of phosphate reabsorption. Clin Chim Acta 1969;26:15-24.

${ }^{18}$ Nordin BEC. Diagnostic procedures. In: Nordin BEC, ed. Calcium, phosphate, and magnesium metabolism. Edinburgh, London, and New York: Churchill Livingstone, 1976:469-524.

${ }^{19}$ Addison GM, Hales CN, Woodhead JS, O'Riordan JLM. Immunoradiometric assay of parathyroid hormone. $\mathcal{F}$ Endocrinol 1971;49:521-30.

20 Harris WH, Heaney RP. Skeletal renewal and metabolic bone disease. $N$ Engl f Med 1969;280:193-202, 253-9, 303-11.

${ }^{21}$ Neer RM, Potts JT. Medical management of hypercalcaemia and hyperparathyroidism. In: de Groot LJ, ed. Endocrinology. Vol II. New York and London: Grune and Stratton, 1979:725-34.

${ }^{22}$ Kanis JA, Russell RGG, eds. Diphosponates and Paget's disease of bone. Metabolic Bone Disease and Related Research $1981 ; 3:$ Nos 4 and 5.

${ }^{23}$ Kaplan RA, Geho WB, Poindexter C, Haussler M, Dietz GW, Pak CYC. Metabolic effects of diphosphonate in primary hyperparathyroidism. f Clin Pharmacol 1977;17:410-9.

(Accepted 11 November 1982)

\title{
Maturity onset diabetes of the young is not linked to the insulin gene
}

\author{
J I BELL, J S WAINSCOAT, J M OLD, C CHLOUVERAKIS, H KEEN, R C TURNER, \\ D J WEATHERALL
}

\begin{abstract}
Maturity onset diabetes of the young is inherited as an autosomal dominant condition. Two families with the disease were studied to determine whether the inheritance of this type of diabetes was linked to the insulin gene. A cloned insulin gene probe was hybridised to DNA from the family members and the insulin gene on each chromosome identified by a different fragment length polymorphism.

The results showed no linkage between the insulin gene and the inheritance of maturity onset diabetes of the young.
\end{abstract}

\footnotetext{
Nuffield Department of Clinical Medicine, John Radcliffe Hospital, Headington, Oxford

J I BELL, MA, MRCP, research fellow

J S WAINSCOAT, MRCP, MRCPATH, MRC training fellow

J M OLD, PHD, senior biochemist

R C TURNER, MD, FRCP, clinical reader

D J WEATHERALL, FRCP, Nuffield professor of clinical medicine

Unit for Metabolic Medicine, Guy's Hospital, London SE1 9RT

C CHLOUVERAKIS, MD, honorary consultant

H KEEN, MD, MRCP, professor of metabolic medicine
}

\section{Introduction}

The genetic basis of non-insulin dependent diabetes mellitus remains poorly understood. Although a high level of concordance exists in twin studies, ${ }^{1}$ a clear pattern of inheritance has not emerged from family or linkage studies. One reason for this is the pronounced heterogeneity of the disease. ${ }^{2}$ A subgroup of non-insulin dependent diabetes in which genetic analysis might prove more fruitful was described by Tattersall and Fajans. ${ }^{34}$ This subgroup, referred to as "maturity onset diabetes in the young," is manifested by non-ketotic diabetes which develops in early adult life and persists with little progression and few complications, and it provides several advantages as a subgroup for genetic analysis. Firstly, it is inherited in a pattern consistent with an autosomal dominant trait; $53 \%$ of siblings are affected and $85 \%$ of patients have a parent with diabetes. This pattern of inheritance allows linkage studies to be performed within families using genetic markers. Secondly, because the disease is usually expressed at a young age it is often possible to analyse several generations of one family and avoid inaccuracies that result from failing to identify subjects who would later develop diabetes.

Results of linkage analysis of affected families with a wide range of genetic markers, including the HLA loci, have all been negative. ${ }^{5}$ The cloning and sequencing of the insulin gene has, however, led to the discovery of a new marker, a highly variable length polymorphism adjacent to the $5^{\prime}$ end of the insulin gene, which may be identified by restriction endonuclease gene mapping. ${ }^{6}$ Patients with maturity onset diabetes of the young often show both low insulin concentrations and a poor response of insulin to glucose challenge ${ }^{78}$; hence it is important to determine whether a locus in the region of the insulin gene is 
responsible for their diabetes. We have studied two families with maturity onset diabetes of the young and report the first linkage analysis between the disease and the insulin gene.

\section{Subjects and methods}

Family 1-The propositus, subject III 2, had been diagnosed as having glucose intolerance during her first pregnancy at the age of 23 and continued to be diabetic. Her daughter was identified as a diabetic at the age of 17 . Her father suffered from diabetes and her paternal grandmother was reported to have had diabetes from an early age. She had one sibling who had also been diagnosed as having diabetes. None of these family members required insulin for their diabetes and there was no evidence of microangiopathic diabetic complications in affected members.

Family 2-The propositus, subject IV 2, was recognised as diabetic at age 17. His mother had been diagnosed as diabetic while pregnant at the age of 24 , and his maternal aunt had been thought to be suffering from diabetes while pregnant in her 20 s but the diagnosis was not confirmed until she was 41 . The maternal grandmother of the propositus had suffered from diabetes from her late teens but never required insulin, and his great grandfather had also had diabetes from a young age. None of the diabetic family members had required insulin.

Paternity was confirmed within each of the families by HLA typing of all available family members.

Restriction enzyme analysis was performed on DNA extracted from heparinised blood samples using phenol-chloroform extraction. ${ }^{\circ} \mathrm{DNA}$ was digested with Rsa 1 enzyme for six to 12 hours in the appropriate buffer with 10 units of enzyme and $10 \mu \mathrm{g}$ of DNA per sample. The digested samples were subjected to electrophoresis in $1.2 \%$ agarose gel for 24 hours at $1.5 \mathrm{~V} / \mathrm{cm}$. The DNA was then transferred to nitrocellulose paper by the Southern blotting technique ${ }^{10}$ and subsequently hybridised to the insulin probe ( $\mathrm{pH}$ Ins 214), which had been labelled with $[\alpha-32 \mathrm{p}] \mathrm{dCTP}$ (Amersham) by nick translation. Hybridisation was performed over 24 hours with 20-25 ng of labelled probe per filter at $42^{\circ} \mathrm{C}$ in buffer containing $10 \%$ dextran sulphate. The filters were subsequently washed at $65^{\circ} \mathrm{C}$ and subjected to autoradiography at $-90^{\circ} \mathrm{C}^{9}$

\section{Results}

Restriction endonuclease analysis of the variable length polymorphism was performed using the enzyme Rsa 1 , which has several advantages over the more commonly used $\mathrm{Bgl} 1$ enzyme. Rsa 1 generates a fragment incorporating part of the insulin gene and variable region that is smaller than the corresponding fragment produced by $\mathrm{Bgl} 1$ (fig 1), thus giving better resolution of small sized

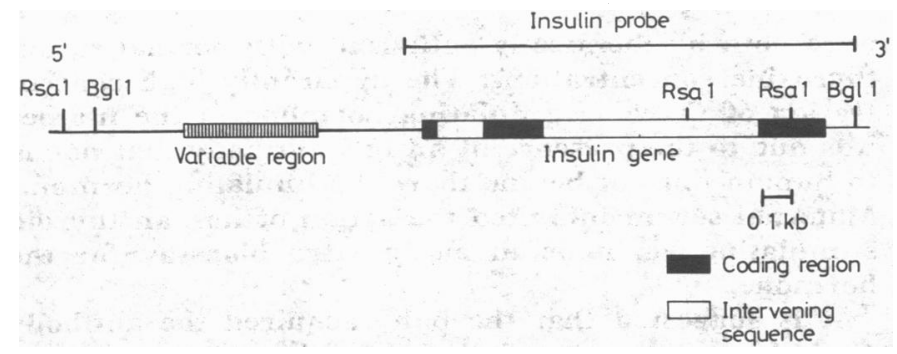

FIG 1-Physical map of insulin gene region showing insulin gene and variable fragment length polymorphism.

fragments. Also the Bgl 1 enzyme recognises a site near the $3^{\prime}$ end of the insulin gene, which is occasionally methylated and hence resistant to digestion. ${ }^{11}$ Such a modification site does not occur at the sequence recognised by $R$ sa 1 , simplifying the interpretation of results.

Digestion of DNA with Bgl 1 gives rise to two variable classes of bands on autoradiography, upper $(U)$ and lower $(L)$, corresponding to long and short DNA variable region inserts, respectively. Similarly digestion of DNA with Rsa 1 from the diabetic patients was found to give bands which could be identified as belonging to either class. In family 1 only the short polymorphic fragments were present but these could be distinguished as being of three different lengths, $L^{a}, L^{b}$, and $L^{c}$. In family 2 both long $(U)$ and short $(L)$ variable fragments were identified (fig 2). Analysis of the pedigrees of the families indicated that the variable region was inherited in a mendelian fashion (fig 3).

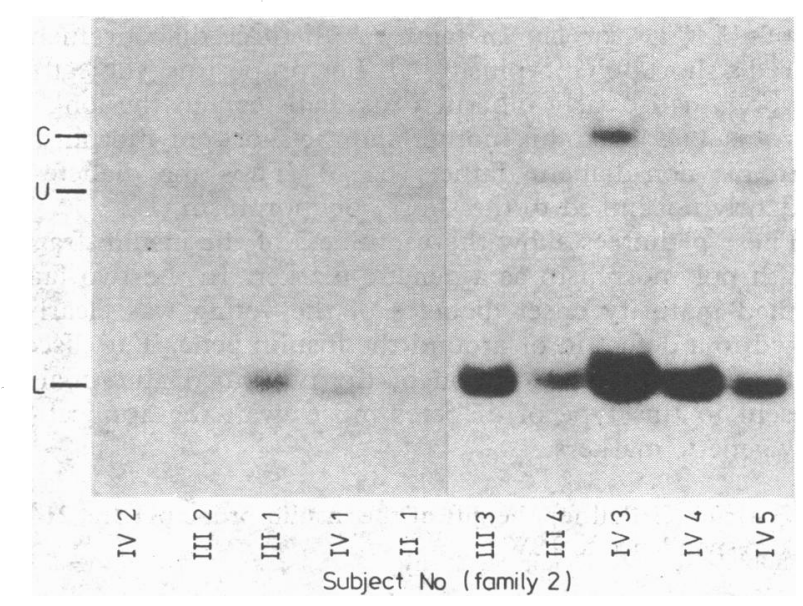

FIG 2-Autoradiograph of DNA from members of family 2 showing long $(U)$ and short $(L)$ variable fragments. Band labelled $C$ is constant to all DNA samples and contains $3^{\prime}$ end of insulin gene.

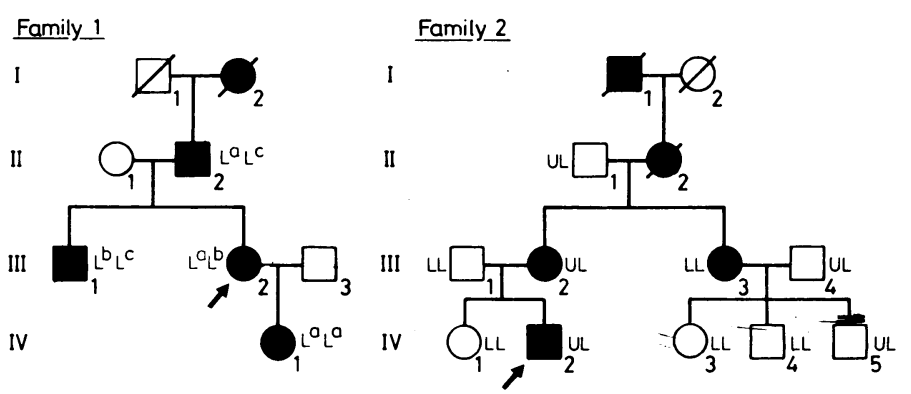

FIG 3-Pedigrees of families 1 and 2. Closed symbols represent family members with maturity onset diabetes of the young. Open symbols represent non-diabetic family members. In family $1 L^{a}, L^{b}, L^{c}$ represent three different sized short variable fragments. In family $2 L$ and $U$ represent short and long variable fragments, respectively. Arrows indicate propositi.

\section{Discussion}

Maturity onset diabetes of the young is the subgroup of noninsulin dependent diabetes most amenable to genetic linkage analysis because of its apparent autosomal dominant inheritance. No family affected by this type of diabetes, however, has yet been shown to have a genetic marker linked to the diabetic phenotype.

Until recently no genetic marker for the insulin gene had been available. Bell and his colleagues cloned and sequenced the insulin gene ${ }^{12}$ and subsequently identified a region of repeated oligonucleotides $5^{\prime}$ to the gene. ${ }^{6}{ }^{18}$ The length of this region was determined by a variable number of repeated oligonucleotides resulting in a distinctively polymorphic region. The length polymorphism fell into two common classes, a short size 0-600 bp (base pairs) in length (L) and a long size 1600-2200 bp in length $(U)$. There have been several studies attempting to relate the frequency of the $\mathrm{L}$ and $\mathrm{U}$ fragments to different types of diabetes, but these have not given consistent results. ${ }^{14-17}$

We used the fragment length polymorphism adjacent to the insulin gene simply as a genetic marker for a linkage study within families. The variability of the polymorphism gives a reasonable probability of finding families in which each chromosome is marked by a different fragment length polymorphism. Three families were originally studied but one was excluded because the members were homozygous for a short fragment 
length polymorphism ( $L L$ ). The two remaining pedigrees studied had diabetic members doubly heterozygous for fragment length polymorphisms, and our results showed no linkage between maturity onset diabetes of the young and the variable region polymorphism. In family 1 the diabetic patients did not share any of the three different short polymorphisms foundthat is, $\mathrm{L}^{\mathrm{a}}, \mathrm{L}^{\mathrm{b}}$, or $\mathrm{L}^{\mathrm{c}}$. In family 2 all three diabetic members shared a short polymorphism (L). The propositus (subject IV 2), however, had clearly inherited his diabetes and the long polymorphism (U) from his mother and the short polymorphism (L) from his non-diabetic father (fig 3). Thus the diabetes was evidently not linked to the short polymorphism (L).

These pedigrees show the usefulness of the insulin fragment length polymorphism as a genetic marker. In the two families studied maturity onset diabetes of the young was clearly not linked to a defect in or around the insulin gene. The discovery of the chromosomal location of the presumed abnormal gene present in this type of diabetes must await the application of new genetic markers.

We thank $G$ Bell for the gift of the insulin probe pH Ins 214 . Correspondence to JSW.

\section{References}

1 Pyke DA. Diabetes: the genetic connections. Diabetologia 1979;17:333-43.

2 Rotter JI, Rimoin DL. The genetics of the glucose intolerance disorders Am $\mathcal{F}$ Med $1981 ; 70: 116-26$.

${ }^{3}$ Tattersall RB. Mild familial diabetes with dominant inheritance. $Q \mathcal{F}$ Med $1974 ; 43: 339-57$.

4 Tattersall RB, Fajans SS. A difference between the inheritance of classical juvenile-onset and maturity-onset type diabetes in young people. Diabetes $1975 ; 24: 44-53$.

${ }^{5}$ Platz P, Jakobsen BK, Suejgaard A, et al. No evidence for linkage between HLA and maturity onset type of diabetes in young people. Diabetologia $\mathrm{C}$ $1982 ; 23: 16-8$.

${ }^{6}$ Bell GI, Karam JH, Rutter WJ. Polymorphic DNA region adjacent to the 5 end of the human insulin gene. Proc Natl Acad Sci USA 1981;78: 5759-63.

Barbosa J, Ramsay R, Goetz FC. Plasma glucose, insulin, glucagon and $\mathbb{D}$ growth hormone in kindreds with maturity-onset type of hyperglycemia in young people. Am F Med 1978;88:595-601.

${ }^{8}$ Fajans SS, Floyd J, Tattersall R, Williamson J, Pek S, Taylor C. The various faces of diabetes in the young. Arch Intern Med 1976;136: $\overrightarrow{\bar{N}}$ 114-202.

${ }^{9}$ Old JM, Higgs DR. Gene analysis. In: The thalassaemias: methods in haematology. Edinburgh: Churchill Livingstone, 1982:74-102.

${ }^{10}$ Southern EM. Detection of specific sequences among DNA fragments $\frac{\bar{\sigma}}{\vec{\sigma}}$ separated by gel electrophoresis. F Mol Biol 1975;98:503-17.

11 Ullrich A, Dull TJ, Gray A, Phillips JA III, Peter S. Variation in the sequence and modification state of the human insulin gene flanking regions. Nucleic Acids Res 1982;10:2225-40.

12 Bell GD, Pictet RL, Rutter WJ, Cordell B, Tischer E, Goodman HM. Sequence of the human insulin gene. Nature 1980;284:26-32.

${ }^{13}$ Bell GI, Selby MT, Rutter WJ. The highly polymorphic region near the $\vec{\omega}$ human insulin gene is composed of simple tandemly repeating sequences. Nature $1982 ; \mathbf{2 9 5}: 31-5$.

14 Rotwein P, Chyn R, Chirgwin J, Cordell B, Goodman HM, Permutt M. Polymorphism in the 5 ' flanking region of the human insulin gene and its possible relation to type 2 diabetes. Science $1981 ; 213: 1117-20$.

15 Owerbach D, Nerup J. Restriction fragment length polymorphism of the insulin gene in diabetes mellitus. Diabetes $1982 ; 31: 275-7$.

16 Bell GI, Horita S, Karam JH. A polymorphic locus adjacent to the human of insulin gene and diabetes mellitus. Diabetes 1982;31,suppl 2:65A. ज़ (Abstract.)

17 Owerbach D, Poulsen S, Billesbolle P, Nerup J. DNA insertion sequences 0 near the insulin gene affect glucose regulation. Lancet $1982 ; \mathrm{i}: 880-3$.

(Accepted 11 fanuary 1983)

\title{
Transient neonatal hyperthyrotrophinaemia: a serum abnormality due to transplacentally acquired antibody to thyroid stimulating hormone
}

\author{
JOHN H LAZARUS, RHYS JOHN, JODY GINSBERG, IEUAN A HUGHES, GERALD SHEWRING, \\ BERNARD REES SMITH, J STUART WOODHEAD, REGINALD HALL
}

\begin{abstract}
In a screening programme for neonatal hypothyroidism an otherwise healthy female infant was found to have a high concentration of thyroid stimulating hormone in a filter paper blood spot and in serum. A high concentration was also found in the maternal serum. Mother and baby
\end{abstract}

\footnotetext{
Department of Medicine, Welsh National School of Medicine, University Hospital of Wales, Heath Park, Cardiff CF4 4XN JOHN H LAZARUS, MD, FRCPGLAS, senior lecturer

JODY GINSBERG, MD, research fellow (present appointment: senior resident, University of Alberta, Canada) GERALD SHEWRING, BSC, biochemist

BERNARD REES SMITH, PHD, reader

REGINALD HALL, MD, FRCP, professor

Department of Medical Biochemistry, Welsh National School of Medicine

RHYS JOHN, PHD, MRCPATH, principal biochemist

J STUART WOODHEAD, PHD, senior lecturer

Department of Child Health, Welsh National School of Medicine IEUAN A HUGHES, MD, MRCP, senior lecturer
}

were both biochemically euthyroid with normal serum thyroxine concentrations. The apparently high concen- $\stackrel{\varrho}{\circ}$ tration of thyroid stimulating hormone in the mother was due to the presence of an IgG antibody that bound $ᄋ$ to human but not bovine thyroid stimulating hormone. N Maternal serum inhibited the action of human thyroid stimulating hormone in an in vitro bioassay for the hormone.

It is suggested that the baby acquired the antibody transplacentally, especially as the concentration of $\omega$ thyroid stimulating hormone subsequently fell. It is concluded that maternal serum should be assayed forco thyroid stimulating hormone when a neonate is found $\Phi$ to have a high concentration of the hormone and $a^{+}$ normal concentration of thyroxine to establish the $\frac{T}{+}$ incidence of this finding and to avoid inappropriate $\frac{\vec{\Phi}}{\mathbb{D}}$ replacement treatment.

\section{Introduction}

Neonatal hypothyroidism may now be detected by screening thyroid hormone concentrations in blood obtained by heel 